\title{
TEACHING STRATEGIES USED IN ESP CLASSES
}

\author{
Kadek Maya Cyntia Dewi ${ }^{1}$, I Gede Galang Surya. P $^{1}$, I Putu Agus Endra Susanta ${ }^{1}$ \\ ${ }^{1}$ Sekolah Tinggi Ilmu Kesehatan Bali \\ e-mail: maya.agapita88@gmail.com,galangsurya1010@gmail.com, ramaendra@gmail.com
}

\begin{abstract}
This study aimed to describe teaching strategies implemented by lecturers in teaching English of continuing program students at STIKES Bali. Descriptive qualitative design use used. There were 2 respondents involved in this study which were lecturers who taught English in continuing program at STIKES Bali. The data were collected by using observation sheet and interview guide. The data were analyzed descriptively according to descriptive qualitative design. The finding showed that there were 5 teaching strategies from 7 teaching strategies proposed implemented by lecturer such as Direct Instruction, Discussion, Group Work, Co-operative Learning and Performance Activity. Direct Instruction and Discussion were the most teaching strategies that chosen by English lecturers. Teaching strategies were implemented according to the topics and characteristics of the students. Choosing the right teaching strategy is very important in teaching English, especially in continuing program students at STIKES Bali. English lecturers in STIKES Bali are expected to implement more and appropriate teaching strategies to improve the quality of teaching and learning process.
\end{abstract}

Keywords : teaching strategies, continuing program, observation, co-operative, quality

\section{INTRODUCTION}

Language is one of important roles for human lives. Through language, people can express their ideas, feelings, reasons, and desires in order to create harmony among them, (Brown, 2010). Based on this definition, language acts as a means of communication that facilitates the need of people as social creatures who cannot live alone on earth.

English is a language for international community. People around the world use English as a tool for communication. In many countries, English is considered as a second language but in Indonesia English is a foreign language. People in Indonesia learn English for some reasons such as to understand and communicate in English, to keep up with the development of science and technology and some of them want to get better job where English is needed.

Nowadays, EFL lecturers need to have better knowledge and skills of various teaching strategies especially in teaching English. There have been long lists of strategies in EFL teaching and learning process that are developed to facilitate the students in learning English. Sometimes those teaching strategies are modified from the conventional ones according to the characteristics of the students and the topic given. Teaching English as foreign language is expected to meet the demand to master all the four language skills: listening, speaking, reading, and writing (Cahyono and Widiati, 2011). Considering the status 
of English in Indonesia as a foreign language, not many people use English in their daily communication either in spoken or written way. People learn English in order to be able to listen, read, speak and write in English; some other to keep up with the development of science and technology, some may learn it because they want to understand English movie or song, or to get job where mastery of English is required (Pressley, 2001).

Teaching English as a second language in Indonesia is a quite a complex task for a teacher or a lecturer. Lecturer need to have effective and innovative teaching strategies in order to grasp better in learning English. The lecturer have to facilitate the students' interest towards learning English.

In foreign language teaching, there have been development and changes of approaches and methods over the years (Celce-Murcia, 2001). Many approaches and methods are available to be used in teaching and learning in language class.

A teacher should create creative activities to get students involved in interaction in English (Isnaini, 2012). In addition, in higher education creativity of the lecturer also needed in teaching and learning process. The use of $s$ suitable strategy by lecturer in teaching English will attract students' attention toward the material presented by the lecturer and make the students actively participate in the learning activities. Therefore, it is crucial to implement an appropriate teaching strategy that can solve the problems. The lecturer should implement an innovative teaching strategies that can bring students out of boredom and competitive. The used of an appropriate teaching strategy not only implement for a teacher in Junior High School or Senior High School, but also in higher education.
In teaching and learning process, lecturers have to know learning strategy in order to make the students learn effectively and efficiently and can achieve the goal of the learning process.

The lecturers need to be taken care about the strategies used in the teaching and learning process. One strategy which is effective to be used in a certain material, might be not effective for another material or topic. It means that lecturers have to use varied teaching strategies in the classroom based on the purpose of the learning process. So, for a different learning purpose, teachers are expected to use different strategy to make the learning process become effective and efficient.

A strategy can be identified as a certain plan designed to control and manipulate certain information in order to reach a particular end (Brown, 1980). Strategies are ways that can be used across curricular areas to support and enhance students' learning (Herrel \& Jordan, 2004). All students at STIKES Bali come from different backgrounds, interests and attitude towards learning. The lecturers are trying to meet students' needs in their learning. Teaching language is a complicated task for teachers and the right techniques and strategies are needed to deliver effective language learning especially in English (Amhaja, 2013). Ellis (1997) stated that as teachers, we need to explore more fully the factors that are involved in motivating students to perform tasks well because this is something that teachers have some control over.

In STIKES Bali, the students are not only from the regular classes (Bachelor in Nursing, Diploma 3 of Nursing, Diploma 3 of Midwifery, and Diploma 4 of Anesthesiology) but also from continuing program students. The students of 
continuing Program are heterogeneous. Most of the students are working in hospital or in government services. They have gap of age difference. Some of them are under 30s and some of them are over 40 s.

Continuing program students of STIKES Bali chosen as the subject of this research because the continuing program students need a specific strategy to be dealt with in the teaching and learning process especially in teaching English. It is quite different with the students in the regular class. Most of them are in similar age level, while in continuing program the students have huge gap in their age. Therefore the lecturer need a specific strategy in teaching them. The researcher interested in doing a research because the huge gap of age difference and the difference of the background of the students.

Considering the differences of age and also characteristic of the students in continuing program, the lecturers may adopt different strategies to reach their goals. They are required to be innovative and creative in using teaching strategy, because it affects the quality of the output. In addition, the use of a suitable strategy will attract students' attention toward the presented material and make the students actively participate in the learning activities.

Regarding this matter, the researcher interested to investigate the strategies used by lecturers in teaching English in continuing program. To answer the curiosity, the researchers formulate the title of this research is "TEACHING STRATEGIES IMPLEMENTED BY LECTURERS IN TEACHING ENGLISH IN CONTINUING PROGRAM AT STIKES BALI".

\section{RESEARCH METHOD}

This research is in the form of qualitative research. It involves describing, analyzing and interpreting of conditions that exist. According to Patton (1987), qualitative research consists of (1) descriptions of events, situation, people, interactions and observed behavior presented in details; (2) direct quotations taken from people' experiences, attitudes, beliefs, and thoughts; and (3) excerpts or entire passages from documents, correspondences, record, and case histories.

Related to this research, the main data were detailed descriptions of teaching strategies implemented by the lecturers in the classroom gathered through recording and note-taking as the activities done by the lecturers in their classes. The other data sources were transcripts of interview with the teachers in order to confirm the use of strategies in classroom activities.

Since this study is a qualitative study, the researcher was the main instrument of the research. The data in this research were collected through two ways, observation and interview. A nonparticipant observation was carried out to collect data concerning classroom activities. In this case, researcher did not disturb the activities in teaching and learning process. The researcher was a complete observer in this study. An observation becomes an effective means of learning to observe how certain teaching strategies are implemented in the classroom, how classrooms are organized, and how students responds to the classroom environment. In this research, semi structured interview was used by the researcher for two English lecturers at STIKES Bali. It was done to get deep information about the implementation of 
teaching strategies applied by English lecturers at STIKES Bali and to confirm about the strategies used in teaching learning process.

The subject of this research were 2 lecturers in STIKES Bali who teach English in continuing program. The data in this research collected through observation and interview.

\section{1) Observation}

In language classroom, observation refers to the purposeful examination of teaching and/or learning events through systematic processes of data collection and analysis (Richards, 2001). The researcher was a complete observer in this study. It means that the researcher tried not to disturb the classroom activities in any way. In doing the observation, researcher used the observation sheet developed from strategies by Killen (1996). The researcher was complete observer, because in this research the researcher observes all activities in the classroom and not directly include in the teaching and learning process. Besides used the observation sheet, the researcher also used handycam to record the conversations or the activities during the teaching and learning process. Tape or video recorder ensure completeness of the verbal interaction and provides material for reliability checks (McMillan and Schumacher, 2010).

\section{2) Interview}

Interview is a directed conversation between the investigator and an individual or group in order to gather information (Richards, 2001). In this research, semi structured interview was used. There were some questions in the list to guidance the researcher in interviewing the lecturers. It was done to get deep information about the implementation of teaching strategies applied by the lecturers in teaching English and to explore the reason of the lecturers why use certain strategy in teaching English in Continuing program at STIKES Bali.
The collected data were analyzed qualitatively through interactive data analysis model which was proposed by Miles and Huberman (1987). This method consisted of three steps, namely: data reduction, data display, and conclusion. The three activities in interactive data analysis can be explained as follow:

1) Data Reduction

Data reduction means summarizing, choosing the subject matters, focusing on things that are important, looking for themes and pattern (Sugiyono, 2010). From the observation sheet and recorded activities in the classroom, the researcher listed all the strategies found during the observation and the activities in which the strategies applied. The result of the interview was also transcribed to support the findings.

2) Data Display

The most frequent form of display data for qualitative research data, as Miles and Huberman stated, is in the form of narrative text. The other forms can be short essay, chart, and connection between categories, flowchart and so forth. By displaying the data, it will be easier to understand what is happening and plan for the next step based on what has been understood from the data (Sugiyono, 2010). In this research, the data were presented in the form of narrative text for the strategies implemented by English lecturers in Continuing program at STIKES Bali, the problems face during teaching English in the classroom, and the reason of the lecturers implemented series of strategies in teaching English.

3) Drawing conclusion/Verification

Drawing the conclusion and verification, according to Sugiyono (2010), is the last step in data analysis. This process was the process where the researcher drawn the conclusion from the available 
data. If the researcher felt that the data were not enough to draw conclusion, data collection process was conducted to get more data and those data were rechecked by doing data reduction and data display. This activity was continued until the researcher felt that the conclusion that was made already answered the research questions.

The data reliability and validity must be tested in order to get acknowledge and trusted data for the result and finding in this research. Reliability deals with the extent to which the result of the study is able to be trusted accurately. Whereas, validity is a circumstance in which the result of this study is usable or acceptable until a definite expiry date or under specific circumstances of use (Maya, 2015). In order to achieve these two things, the researcher as the key instrument should be consulted before observing and collecting the data of strategies used by lecturers in teaching English in continuing program at STIKES Bali.

Triangulation method was used in this study such as time-based triangulation. As what is explained by Sugiyono (2012), time-based triangulation is a triangulation that is done by collecting the same data from the same resource repeatedly and compared the result of the data collection from time to time. And it was verified again in the observation by using nonparticipant observation.

Data triangulation means comparing and rechecking the reliability of the information gathered on different occasion by using different devices. On this study, the data triangulation were done by having informal interviews with the researcher and English teacher about the strategy that they use in the teaching speaking to their students.

Bogdan and Sari (1982) stated the use of triangulation by stating triangulation "Strengthen the Study by Combining Several Methods of Data Collection" which included interview, observation and document analysis. In this research, several methods of data collection were done namely: interview, observation, and recording.

\section{FINDINGS AND DISCUSSION}

\section{A. FINDINGS}

Based on the results of the observation and interview of 2 English lecturers at STIKES Bali, especially the students of continuing program Academic Year 2017/2018. The researcher coded the lecturer into L1 for the first lecture and L2 for the second lecturer.

\section{Teaching Strategy used in Teaching} English in Continuing Program

In this section, the researcher presents data related to the strategy used by the English lecturer of STIKES Bali which is used to teach the students of $1^{\text {st }}$ semester students of continuing program Academic Year 2017/2018. The teaching strategy used by the lecturer was different depend on the material presented, this is related to the opinion of Killen (2010) about the teaching strategy which is the approach used by lecturers for certain lessons and the specific objectives of the lesson.

In the teaching and learning process, a lecturer has to know the learning strategies to help students achieve the goals of the learning process. Moreover, one strategy that is used tends to be suitable for certain material, may not be effective for other material. In this case the possibility of the lecturer will use various strategies in teaching English based on the learning objectives. 
Therefore, for different learning objectives, lecturers are expected to use different strategies so that the learning process becomes effective and efficient.

To find out the strategy used by the lecturer, the researcher also brings an observation sheet to observe teaching and learning activities in the classroom. Lecturers they had their own way of giving lectures related to the topics. From the results of observations on L1 on December $17^{\text {th }}$ of December 2017, there were 2 points which were not implemented in the class, the first point was in item 12 of the observation sheet related to Lecturers giving students the opportunity to perform in front of the class (speaking \& reading), which in this case in L1 class, there were no students who had the opportunity to perform in front of the class. Then there was point 13 about students making a research report, which in L1class there was no research report made by the students. In L2 class, researchers have researched 3 times, namely on December $10,2017,24^{\text {th }}$ of December 2017, and $14^{\text {th }}$ of January 2018. From the observations on L2 on $10^{\text {th }}$ of December 2017 and $14^{\text {th }}$ of January 2018, there were 3 points which were not implemented in class, the first point was in item 2 of the observation sheet related to the Lecturer dominates the activities in the classroom, in this case in L2 class, there was no visible dominance with the lecturer who always gives the latest cases and asks students to talk more in class. The second point was in item 12 of the observation sheet related to Lecturers giving students the opportunity to appear in front of the class (speaking \& reading), which in this case is in L2 class, there were no students who have the opportunity to appear in front of the class but students simply give ideas and ideas from where they sit. Then in point 3 , there was point 13 about students making research reports, which in L2 class there was no research report making activity. From the observations on L2 on $24^{\text {th }}$ of December
2017, there were 2 points which were not seen in class, the first point is in item 12 of the observation sheet related to Lecturers giving students the opportunity to appear in front of the class (speaking \& reading), which in this case in L2 class, there were no students who had the opportunity to appear in front of the class. Then there was point 13 about students making a research report, which in L2 class there was no research report making activity.

From the observation on $\mathrm{L} 2$ on $14^{\text {th }}$ of January 2018, there were no problem solving materials and student research used in the class. There are direct instructions that provide material for administering medicine administration procedures that involve students to provide responses related to information on drug administration by role playing. Discussion, group work and cooperative learning activities were also used when giving explanations related to alternative expressions that can be used in providing care. From 3 meetings, L1 used 5 of the 7 strategies in the three meetings by Killen (2010). There are 4 English lecturers teaching in continuing program, but only 2 lecturers will be examined in this study. From the two lecturers, researcher observed teaching and learning activities in the classroom to see the teaching strategies used by English lecturers.

In the implementation, the students' intentions and motivations become one of the things that should be noted, this is in accordance with Mounawar (2013) in the application of teaching strategies. From the interview results on L1, the students' intentions and motivation in learning English were quite high, as evidenced by the presence of students in the class which was quite large and the students actively asked the question. L1 and L2 students are very enthusiastic and quite motivated by using the suitable teaching strategy. So from the 7 teaching strategies proposed by Killen, 2 teaching strategies tend not to be used, 
namely Problem Solving and Student Research by the two lecturers.

\section{Reasons of the lecturers in Using English Teaching Strategies on continuing program.}

The existence of teaching strategies will greatly affect learning outcomes as well as being influenced by the motivation of students who are quite motivated in the lectures. Both lecturers, are strongly support the suitable teaching strategies in the. In terms of determining teaching strategies that can be used in class, D1 assumes that determining teaching strategies based on class characteristics, this is because between 1 class with another class usually has different characteristics, so the method in one class is not necessarily appropriate for use in class other. In addition, L1 also saw the ability distance / proficiency gap of students in the class.

The teaching method for classes with the same abilities will be different from the method of teaching in a class where students have a considerable ability distance in English proficiency. Whereas in L2, there are several factors that are considered in determining appropriate strategies, such as: classroom environment, class atmosphere, and lecture participants, which in this case are B program students, which are adult learners, so the provision of material must be adjusted accordingly, so that it is well received by students, the delivery of material becomes the third point that is able to determine the material delivered, if the classroom environment becomes sluggish, the insertion of the game can stimulate student activity, and others. In classifying each skill, agree with L1, which in this case $\mathbf{L 2}$ depends on the schedule that has been given in the lecture, so in this case L2 integrates all skills, because teaching by using the environment around students as a parable can build similar conditions, besides also students will be assisted by the experience they already have

The strategy used in listening skills by L1, uses several strategies such as Gap-Filling in the text, namely by put blank in text or dialogue, also through songs by selecting songs that are quite popular and asking students to listen and fill in the gaps in the text of the song. In addition, L1 also uses strategies by inviting students to watch films related to health and nursing, usually L1 chooses one episode of TV-Series Grey's Anatomy with English subtitles. The lecturer also watches the film so the lecturer clarifies conversations heard with the correct sentence. After that the lecturer as the facilitator will lead the discussion about the episode that has been watched. L1 carries out the learning of each skill by using appropriate activities such as: 1) In Speaking skill learning, L1 generally asks students to make small groups (2 students) or larger groups ( 3 - 4 students) to discuss and make a kind of conversation related to topics that have been discussed in class. After that students were asked to appear in class practicing speaking. In addition, L1 also asks students to use English as much as possible when talking with classmates of students or with L1 when English language lesson; 2) In continuing program L1 does not teach Reading. Only Speaking and Listening. 3) In teaching Listening. a) L1 prepares listening material, usually for the first listening meeting L1 prepares a simple conversation between the nurse and patient, for example the topic of getting patient data and complaints that are felt by the patient. b) L1 asks students to complete the data form \& 
patient complaints based on the dialogue they hear. c) L1 then plays the tape with $3 x$ repetitions. d) After that, L1 repeats the tape-recording if the students found difficulties so they can learn to listen more closely; 4) In teaching writing, L1 does not have the appropriate activities because it is not taught in continuing program. L1 has focused on activities that only focus on speaking skills, listening and reading.

The reason of L1 in using appropriate strategies because of these strategies is needed to prepare learning from becoming monotonous so that a variety of strategies is needed. In addition, these strategies also force students to become more active, discuss with friends in their groups so that the learning process becomes more active and the lecturer is no longer a center of the teaching and learning process. Furthermore, in L2 class, the strategies used by L2 will be adjusted to the class conditions, therefore requiring a variety of treatments

\section{The Most Effective Teaching Strategy used by the Lecturer in Continuing Program}

The existence of multimedia used in teaching also plays an important role. L1 uses various sources such as audio, visuals, printed papers, and PPT and L2 using whiteboards and slides while presenting the material. In facilitating students who have different abilities, L1 gives more attention and involves them to work in groups so that they can learn from their friends. L2 facilitates them by grouping their students in discussion sessions, and giving the opportunity to the student to answer questions as well as giving rewards or praise when they answer the question

Both of the lecturers have their own criteria in determining appropriate teaching strategies, as in L1 does not have specific criteria, because one strategy may not be used in all classes or for all students. The important thing is that the strategy must be able to encourage students to actively participate and motivate to communicate. Meanwhile, L2 in teaching English assumes that a strategy that emphasizes speaking will take precedence.

The most effective teaching strategy is applied in teaching English in continuing program by L1 such as making class circumstance more dynamic, making students work in group so that all students can involve to discuss the topic, and L2 emphasizes on adjusting strategies to student needs, speaking is an important point, so the dynamic teaching strategy which is adapted to the classroom situation will be more effective.

\section{B. DISCUSSION}

STIKES Bali lecturers use Direct Instruction strategy to introduce new topics to the students. This is because this strategy is suitable for introducing material used as brainstorming on new materials that can be linked to conditions in the classroom. The lecturers always check student activities and explain to them if there are problems found by students during discussions.

The discussion is a gradual stage for interaction between groups which in this case pairs, students then exchange problems and ideas which are used to overcome a problem, answer questions, understand their knowledge and decision making (Killen, 2010). In this case, the lecturers ask students to understand the information provided by the lecturer on topics given to students in pairs, and students discuss them by exchanging ideas and opinions, developing their understanding by integrating with previous knowledge and their experiences until they get results. When students get into trouble working on their assignments, students will ask the lecturer about the problem. 
To make students more active in class, the lecturers also stimulate students with various types of activities, even by carrying a few jokes in learning when the class starts to feel tense. In choosing groups, the lecturers usually choose them in pairs, namely students who sit side by side as a group. This is because the different level of the ability of the students in continuing program.

Based on the findings, there are two teaching strategies that are not implemented by the lecturers at STIKES Bali, namely Problem Solving and Students Research. From the results of the interviews that have been carried out, the strategies were not implemented because of the level of students and the objectives of learning. The lecturers have difficulty in adjusting to the different abilities of students. Although most students are able to attend lectures well, there are some that require individual treatment.

\section{CONCLUSION}

STIKES Bali lecturers have demonstrated various teaching strategies in facilitating continuing program students to achieve learning goals. In strategy implementation, there is no specific strategy used in the classroom based on 4 class observations carried out by the researcher. In accordance with L1, in L2, students are very enthusiastic and quite motivated by using the example to motivate students in teaching and learning activities in discussion. As for the 7 strategies that have been proposed by Killen (2010), some of them are indicated by the observations by the two lecturers in teaching English to continuing program students, namely Direct Instruction, Discussion, Group Work. , Cooperative Learning and Performance Activities and 2 strategies tend not to be used, namely Problem Solving and Student Research by the two lecturers. This research has implications for the importance of understanding the type of teaching strategy to improve the quality of lectures in the classroom especially in continuing program at STIKES Bali.

\section{ACKNOWLEDGEMENTS}

Author would like given a huge thanks to family for the advise, motivation, and full of patience in guiding, so this research can be done properly.

\section{REFERENCES}

Amjaha, Y. 2013. A study of teachers' strategies so develop students' interest towards learning English as a second language. University of Brunei Darussalam

Brown, G. G. 2010. All about Theories for Communication 2nd Edition. San Francisco: Addison Wesley Longman, Inc.

Brown, Douglas H. 1980. Principles of Language Learning and Teaching: Prentice Hall, Inc

Cahyono, Bambang Yudi and Utami Widiati. 2011. The Teaching of English as a Foreign Language in Indonesia. Malang: State University of Malang Press

Celce-Murcia, Marianne. 2001. Teaching English as a second or Foreign Language, third edition. USA: Heinle \& Heinle Thomson Learning Inc.

Ellis, R. 1997. Second language acquisition. Oxford: Oxford University Press.

Isnaini, Moh. Hasbullah. 2012. Improving the Speaking Ability of the Tenth Graders of Smk Negeri 1 Singosari Malang through the Think Pair Square

Mounawar, Alsayed. 2003. Factors That

Contribute to Success in Learning English as a Foreign Language. Faculty of Arts and Humanities Damascus 
University. Damascus University Journal

Patton, Michael Quinn. 1987. Qualitative Evaluation Methods. USA : SAGE Publications Ltd.

Pressley, M. 2001. A study of effective first-grade literacy instruction. Scientific Studies of Reading

Richards, J.C. and Rodgers, T.S. 2001. Approaches and Methods in Language Teaching (2nd ed.). Cambridge: Cambridge University Press

Sugiyono, 2012. Metode Penelitian Kuantitatif, Kualitatif, dan $R \cap D$. Afabeta: Bandung 